\title{
Isolation of an Acidic Protein from Cholesterol Gallstones, which Inhibits the Precipitation of Calcium Carbonate in Vitro
}

\author{
Shuji Shimizu, Boris Sabsay, ${ }^{\ddagger}$ Arthur Veis, ${ }^{\ddagger}$ J. Donald Ostrow, Robert V. Rege, ${ }^{\star}$ and Lillian G. Dawes* \\ Gastroenterology Section, Department of Medicine, and ${ }^{*}$ Department of Surgery, Veterans Administration Lakeside Medical Center \\ and Northwestern University Medical School; ${ }^{\ddagger}$ Division of Oral Biology, Northwestern University Dental School, Chicago, Illinois 60611
}

\begin{abstract}
In seeking to identify nucleating/antinucleating proteins involved in the pathogenesis of cholesterol gallstones, a major acidic protein was isolated from each of 13 samples of cholesterol gallstones. After the stones were extracted with methyl $t$-butyl ether to remove cholesterol, and methanol to remove bile salts and other lipids, they were demineralized with EDTA. The extracts were desalted with Sephadex-G25, and the proteins separated by PAGE. A protein was isolated, of molecular weight below $10 \mathrm{kD}$, which included firmly-bound diazo-positive yellow pigments and contained $24 \%$ acidic, but only $7 \%$ basic amino acid residues. The presence of $\boldsymbol{N}$-acetyl glucosamine suggested that this was a glycoprotein. This protein at concentrations as low as $2 \mu \mathrm{g} / \mathrm{ml}$, but neither human serum albumin nor its complex with bilirubin, inhibited calcium carbonate precipitation from a supersaturated solution in vitro. This protein could be precipitated from $0.15 \mathrm{M} \mathrm{NaCl}$ solution by the addition of $0.5 \mathrm{M}$ calcium chloride. Considering that cholesterol gallstones contain calcium and pigment at their centers, and that small acidic proteins are important regulators in other biomineralization systems, this protein seems likely to play a role in the pathogenesis of cholesterol gallstones.
\end{abstract}

\section{Introduction}

Since the initial proposal that cholesterol supersaturation in bile plays a role in the pathogenesis of cholesterol gallstones (1), it has been pointed out that even biles without gallstones are often supersaturated (2). Holan et al. demonstrated that the nucleation time is a better discriminator of biles with and without gallstones (2). It has been shown, in model bile systems, that normal bile contains factors that inhibit nucleation of cholesterol (3), whereas lithogenic biles contain factors that promote such nucleation (4), and that these factors are probably proteins $(3,5)$. Subsequently, biliary apolipoproteins AI

This work was presented in part at the meetings of the American Association for the Study of Liver Diseases, Chicago, IL, October 1987 and November 1988 and published in abstract form in 1987. (Hepatology. 7:1023, and 1988. Hepatology. 8:1257.)

Address reprint requests to Dr. Ostrow, $(111 \mathrm{G})$ V.A. Lakeside Med. Ctr., 333 E. Huron St., Chicago, IL 60611.

Dr. Shimizu was a Visiting Scholar from the Department of Surgery I, Kyushu University, Fukuoka, Japan.

Received for publication 29 March 1989.

J. Clin. Invest.

(C) The American Society for Clinical Investigation, Inc.

$0021-9738 / 89 / 12 / 1990 / 07 \$ 2.00$

Volume 84, December 1989, 1990-1996 and AII have been identified as inhibitors of cholesterol nucleation (6), and a 130-kD glycoprotein has recently been isolated from human hepatic bile that promotes nucleation of cholesterol from bile $(7,8)$. In addition, cholesterol/lecithin vesicles (9) are now recognized to be the macromolecular aggregates in bile from which cholesterol crystals nucleate (10).

Cholesterol, however, is not the whole story. Calcium is an important constituent of all kinds of gallstones, and is almost always present in the center of even "pure" cholesterol stones (11-14). In analogy with cholesterol, calcium salt precipitation is possible only when bile is supersaturated with the salt, i.e., when the product of the activities of the calcium ion and a "calcium sensitive" anion (e.g., carbonate) exceeds the solubility product for that salt (15). Hepatic bile, however, is always supersaturated with calcium carbonate, even in the absence of stones, and normal gallbladder bile can tolerate massive supersaturation with calcium carbonate without precipitation of this salt $(16,17)$. Sutor et al. (18) and Dawes et al. (19) have shown that normal bile inhibits calcium carbonate precipitation in vitro, and thus presumably contains factors that account for the extreme metastable solubility of calcium carbonate seen in normal bile.

Formation of gallstones may be considered to be analogous to formation of shell or bone in biomineralization systems, all of which contain small acidic proteins, usually below $30 \mathrm{kD}$, that regulate the precipitation and accretion of calcium salts (20). Such acidic proteins have been found in the mineralized matrix of sea shells (21), avian eggshells (20), bone and dentin (22), as well as in urinary (23) and pancreatic (24) calculi. We, therefore, hypothesized that acidic proteins might exist also in gallstones, and that they might have some role in gallstone pathogenesis. In addition, such proteins should be selectively concentrated in the stones as compared to the bile, facilitating their isolation. We chose initially to study cholesterol stones because, in comparison with pigment gallstones, they are usually uninfected and the composition of their nonprotein components is simple and well defined (25). In confirmation of our hypotheses, we now report the purification and characterization of a very low molecular weight acidic protein from cholesterol gallstones that binds bilirubin tightly and can arrest precipitation of calcium carbonate in vitro. This protein was selected for analysis because it was the only one below $30 \mathrm{kD}$ that was present in all 13 stones, it had not been reported previously, and it bound bilirubin tightly.

\section{Methods}

Procurement and initial handling of cholesterol gallstones. Human cholesterol gallstones were collected at cholecystectomy from 13 patients, after informed consent. The study was approved by the combined Instutional Review Board of the McGaw Medical Center of Northwestern University. The stones were washed extensively with deionized water, blotted dry, and stored over anhydrous calcium sul- 
fate in the dark, either at $-20^{\circ} \mathrm{C}$, or in vacuo at $22^{\circ} \mathrm{C}$, and then pulverized with an agate mortar and pestle.

Extraction of cholesterol gallstones to remove nonprotein components. The pulverized stones were placed in a Teflon thimble in a Soxhlet apparatus and cholesterol was extracted with methyl $t$-butyl ether (MTBE), ${ }^{1}$ until the weight of the residue remained constant (3-4 d). Bile acids were then removed with methanol. Parts of the residues from six stones were subjected to amino acid analysis at this step in order to measure gamma-carboxyl glutamate (Gla) and to estimate the overall amino acid composition of the whole sample. Each residue was then demineralized three times, for $4 \mathrm{~d}$ each time, at $4^{\circ} \mathrm{C}$ with $0.5 \mathrm{M}$ EDTA in $50 \mathrm{mM}$ Tris/ $\mathrm{HCl}$ buffer, $\mathrm{pH} 8.0$; the solution contained, as protease inhibitors, $2.5 \mathrm{mM}$ benzamidine hydrochloride, $50 \mathrm{mM}$ epsilon-amino- $n$-caproic acid, $0.5 \mathrm{mM} N$-ethylmaleimide and $0.3 \mathrm{mM}$ PMSF (Sigma Chemical Co., St. Louis, MO). After demineralization, the solution was centrifuged at $10,000 \mathrm{~g}$ for $20 \mathrm{~min}$ and $50 \mathrm{ml}$ supernatant was applied to a $2.5 \times 50 \mathrm{~cm}$ column of Sephadex G-25 (Pharmacia Fine Chemicals, Piscataway, $\mathrm{NJ}$ ), that was preequilibrated and eluted with $0.15 \mathrm{M} \mathrm{NaCl}$. The yellow fraction in the void volume was collected, passed through a $0.22-\mu \mathrm{m}$ Millex GV filter (Millipore, Bedford, MA), and the filtrate concentrated by ultrafiltration at $4^{\circ} \mathrm{C}$ (YM5 membrane; Amicon, Danvers, MA).

Purification of protein by PAGE. Purification of the protein for amino acid analysis and determination of its approximate molecular weight was performed by PAGE, using the Laemmli buffer system (26). Running gels were $12 \%$ acrylamide in $0.375 \mathrm{M}$ Tris $/ \mathrm{HCl}, 0.1 \%$ SDS at pH 8.8. Stacking gels were $4 \%$ acrylamide in $0.125 \mathrm{M} \mathrm{Tris} / \mathrm{HCl}$, $0.1 \%$ SDS at $\mathrm{pH}$ 6.8. Samples were dissolved with an equal volume of the sample buffer $(0.1 \mathrm{M}$ Tris/ $\mathrm{HCl}, \mathrm{pH} 6.8,2 \% \mathrm{SDS}, 8 \%$ 2-mercaptoethanol, $12 \%$ sucrose, and $0.005 \%$ bromphenol blue), and then boiled for $10 \mathrm{~min}$ before application. Low and high molecular weight protein standards (Bio-Rad Laboratories, Richmond, CA), and a mixture of cytochrome $c$, trypsin inhibitor and insulin as very low molecular weight references (Sigma Chemicals), were applied in separate lanes. The gel was run at $200 \mathrm{~V}$ in a Mini-Protean II unit (Bio-Rad Laboratories) until the dye front was 1-2 mm above the bottom of the gel $(\sim 40 \mathrm{~min})$. Protein bands were identified by silver staining according to Wray et al. (27). For amino acid analysis, the yellow protein band at $<14 \mathrm{kD}$ was collected without staining and eluted with $25 \mathrm{mM}$ Tris and $192 \mathrm{mM}$ glycine, using the Electroeluter (Bio-Rad). Salts and SDS were removed from this protein by repeated passage through Sephadex G-25 and elution with $0.15 \mathrm{M} \mathrm{NaCl}$, followed by dialysis overnight at $4^{\circ} \mathrm{C}$ against distilled, deionized water with three changes, and then lyophilization.

To preserve the function of the protein and to avoid the effects of bound SDS, the yellow protein was also isolated by preparative native PAGE, without SDS, 2-mercaptoethanol or bromophenol blue, and without heating before application. The main yellow band, which ran close to the buffer front, was collected without staining, electroeluted, and the buffer changed to $0.15 \mathrm{M} \mathrm{NaCl}$ by passage through Sephadex G-25. This protein solution was used for studies of the inhibition of calcium carbonate precipitation in vitro.

Amino acid analysis. Proteins were hydrolyzed in $6 \mathrm{~N} \mathrm{HCl}$ for $22 \mathrm{~h}$ at $108^{\circ} \mathrm{C}$ in vacuo, and amino acid compositions determined with an ion exchange column on an automated amino acid analyzer (model 6AH; JEOL, Tokyo, Japan), using a single column procedure and ninhydrin detection (28). Amino acid concentrations were determined by reference to standard solutions containing $50 \mathrm{nmol}$ of each amino acid. For analysis of Gla, hydrolysis was performed instead with $2 \mathrm{~N}$ $\mathrm{KOH}$, which preserves this residue (28), and the Gla fraction then subjected to the acid hydrolysis to detect glutamic acid.

Precipitation of stone proteins with calcium chloride. To the demineralized protein mixture eluted from Sephadex G25 in $0.15 \mathrm{M} \mathrm{NaCl}$, powdered calcium chloride was added with stirring to a final concen-

1. Abbreviations used in this paper: Gla, gamma-carboxyglutamic acid; MTBE, methyl $t$-butyl ether; UCB, unconjugated bilirubin IX-alpha. tration of $0.5 \mathrm{M}$, and then kept at $4^{\circ} \mathrm{C}$ for $3 \mathrm{~d}$. After centrifugation, both the supernatant and the precipitate were analyzed by SDS-PAGE, as described above.

Protein assay. This was performed with the Coomassie brilliant blue method using the Bio-Rad protein assay kit. To $0.1-\mathrm{ml}$ samples, $5.0 \mathrm{ml}$ dye solution was added, and absorbance measured at $595 \mathrm{~nm}$ after $10 \mathrm{~min}$, with bovine serum albumin (Bio-Rad Laboratories) as a reference standard.

Composition and binding of the yellow pigment. The diazo reaction on the purified protein was performed with Michaelsson's method (29). Dialysis of the purified protein in the presence of urea and mercaptoethanol was carried out to determine the effect on the dialyzability of the pigment in the presence of reagents that break hydrogen and disulfide bonds $(30,31)$. The control was human serum albumin (HSA) (Sigma Chemical Co.) $(8.0 \mathrm{mg} / \mathrm{ml})$ with unconjugated bilirubin (UCB) (Sigma) noncovalently bound at a UCB/HSA molar ratio of $1 / 5$. Samples $(2.5 \mathrm{ml})$ in a $3.5-\mathrm{kD}$ mol wt cut-off membrane (Spectra Por 3; Spectrum Medical Industries, Los Angeles, CA) were dialyzed in the dark against $12 \mathrm{ml}$ buffer $(0.5 \mathrm{M}$ Tris/ $\mathrm{HCl}, \mathrm{pH} 9.1$, containing $0.075 \mathrm{M} \mathrm{NaCl}, 8 \mathrm{M}$ urea and $0.2 \mathrm{M} 2$-mercaptoethanol) at $4^{\circ} \mathrm{C}$ while shaking at $150 \mathrm{rpm}$. Before and after $40 \mathrm{~h}$ of dialysis, OD of the dialysand and dialysate were measured at $420 \mathrm{~nm}$ for the yellow gallstone protein and at $440 \mathrm{~nm}$ for the HSA-UCB control.

Inhibition of calcium carbonate precipitation in vitro. The purified protein samples from native PAGE were examined for their effect on calcium carbonate precipitation in vitro, using the system of Dawes et al. (19). Briefly, $0.2 \mathrm{ml}$ of $0.15 \mathrm{M} \mathrm{NaCl}$, with or without $1 \mathrm{mg}$ protein per $\mathrm{ml}$, was added to $10 \mathrm{ml}$ of $25 \mathrm{mM}$ sodium bicarbonate ( $\mathrm{pH} 8.7$ ) in a 3.5 by $5.0 \mathrm{~cm}$ (diameter by height) polystyrene container (Precision Systems, Sudbury, MA) at $23 \pm 2^{\circ} \mathrm{C}$. Then, at time $0,10 \mathrm{ml}$ of $16 \mathrm{mM}$ calcium chloride was added while stirring at $\sim 500 \mathrm{rpm}$ without vortex, using a $1-\mathrm{cm}$ magnetic Teflon stirring bar. In the absence of inhibitors, precipitation occurs rapidly from this solution, which contains calcium carbonate ion products that are over 1,000 times its reported solubility product (16). The hydrogen ion generated, as calcium carbonate was formed from the reaction of calcium chloride with sodium bicarbonate, was monitored for $15 \mathrm{~min}$ by the decrease in $\mathrm{pH}$ (electrode 91-03; Orion, Cambridge, MA, with digital pH meter 110; Corning, Medfield, MA). Turbidity, resulting from formation of calcium carbonate macrocrystals, was monitored simultaneously by the increase of absorbance at $570 \mathrm{~nm}$ (spectrophotometer 100-40; Hitachi, Tokyo, Japan).

\section{Results}

Gallstones were solitary or multiple, with cumulative dry weights ranging from 1.0 to $20.6 \mathrm{~g}$. After MTBE extraction, the residue ranged from 0.7 to $20.1 \%$ of stone weight, indicating 99.3 to $79.9 \%$ cholesterol content. 8 of the 13 stones contained $>96 \%$ cholesterol, and grossly appeared to be so-called "pure" cholesterol stones.

Amino acid analysis of the whole stone protein residue. The overall amino acid composition of the whole proteins in the first six gallstones obtained was determined by amino acid analysis of the residues remaining after extraction of the stones with MTBE and methanol (Table I). Three of the stones contained $>98 \%$ cholesterol, whereas the other three had visible pigment outside the center and contained 89 to $96 \%$ cholesterol. In all six stones, the proteins were acidic, with a high content (mean 21.4 residue \%) of the acidic amino acids, aspartate and glutamate, as compared with only 10.1 residue \% of the basic amino acids, lysine, arginine, and histidine. There were also high percentages of aliphatic amino acids (glycine, alanine, valine, isoleucine, and leucine) as well as the hydroxylated residues, serine and threonine. Gla was not detected, and there was a low content of amino sugars $(\mathrm{N}$-acetyl glucos- 
Table I. Amino Acid Composition of the Whole Proteins and the Purified Small Acidic Protein of Cholesterol Gallstones*

\begin{tabular}{|c|c|c|c|c|}
\hline \multirow{2}{*}{$\begin{array}{c}\text { Amino } \\
\text { acids }\end{array}$} & \multirow{2}{*}{$\begin{array}{l}\text { Whole } \\
\text { protein }^{\ddagger}\end{array}$} & \multicolumn{3}{|c|}{ Purified small acidic protein } \\
\hline & & Stone A & Stone B & Mean \\
\hline & mean $\pm S D$ & & & \\
\hline Lys & $4.0 \pm 0.5$ & 3.6 & 3.5 & 3.6 \\
\hline His & $1.7 \pm 0.6$ & 1.4 & 1.7 & 1.5 \\
\hline Arg & $4.4 \pm 1.0$ & 2.2 & 1.3 & 1.8 \\
\hline Asp & $10.3 \pm 0.5$ & 13.4 & 12.3 & 12.9 \\
\hline Thr & $6.0 \pm 1.0$ & 4.6 & 4.9 & 4.8 \\
\hline Ser & $7.0 \pm 1.0$ & 5.4 & 6.7 & 6.1 \\
\hline Glu & $11.1 \pm 0.5$ & 12.3 & 10.8 & 11.5 \\
\hline Pro & $6.0 \pm 0.7$ & 7.5 & 7.5 & 7.5 \\
\hline Gly & $12.1 \pm 3.4$ & 22.1 & 22.2 & 22.1 \\
\hline Ala & $9.8 \pm 0.7$ & 10.0 & 10.9 & 10.5 \\
\hline $1 / 2$ Cys & $2.6 \pm 0.6$ & 0.0 & 1.3 & 0.6 \\
\hline Val & $4.4 \pm 0.3$ & 7.0 & 5.9 & 6.5 \\
\hline Met & $1.4 \pm 0.3$ & 0.0 & 0.0 & 0.0 \\
\hline Ile & $1.7 \pm 0.5$ & 1.6 & 1.4 & 1.5 \\
\hline Leu & $7.9 \pm 0.1$ & 5.3 & 5.9 & 5.6 \\
\hline Tyr & $2.7 \pm 0.4$ & 0.0 & 0.0 & 0.0 \\
\hline Phe & $4.5 \pm 0.2$ & 1.9 & 2.3 & 2.1 \\
\hline GluNH $_{2}$ & $2.4 \pm 0.7$ & 1.7 & 1.4 & 1.5 \\
\hline $\mathrm{GalNH}_{2}$ & $0.1 \pm 0.2$ & 0.0 & 0.0 & 0.0 \\
\hline
\end{tabular}

* Data reported as percent residues.

‡ Average of six stones containing $88-99 \%$ cholesterol.

amine, $2.4 \pm 0.7 \%, N$-acetyl galactosamine, $0.1 \%$ ). No peaks were seen when unconjugated bilirubin IX-alpha (UCB) (Sigma) was hydrolyzed with $\mathrm{HCl}$ and injected into the amino acid analyzer, and bilirubin, added to the protein, did not alter the measurements of amino acid composition.

SDS-PAGE of the gallstone proteins in the eluate from Sephadex G25. Fig. 1 shows two examples of SDS-PAGE of the demineralized Sephadex G25 eluate. Proteins from one stone (lane 2) consisted largely of a major band below $14 \mathrm{kD}$ plus a few other faint bands. 8 of the 13 stones showed this pattern, and five of these eight stones had less than $96 \%$ cholesterol. Proteins from a second stone (lane 3) showed the same intense band below $14 \mathrm{kD}$, but exhibited other major protein bands ranging from 10 to $68 \mathrm{kD}$. This pattern was representa-

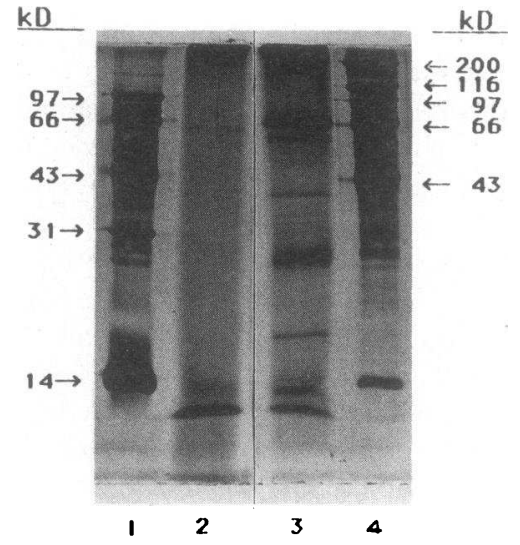

Figure 1. SDS-PAGE (12\% polyacrylamide) of proteins from demineralized cholesterol gallstone residues, excluded from Sephadex G25. Lane 1 , low molecular weight protein standards; lanes 2 and 3 , protein fractions of two different cholesterol gallstones, eluted from Sephadex G25; lane 4, high molecular weight protein standards. tive of five of the stones, all of which contained $>96 \%$ cholesterol. Thus, although stones with the highest cholesterol content contained the least protein, there was a greater variety of proteins in those stones (chi-square $=4.23, p<0.02$ ). The lowest molecular weight protein and proteins of $>200 \mathrm{kD}$ were the only ones that were present in all 13 stones. This small protein was always intensely yellow (absorbance maximum at $420 \mathrm{~nm}$ in $0.15 \mathrm{M} \mathrm{NaCl}$ solution), due to a firmly bound pigment that was not dissociated by either SDS-PAGE or the preceding demineralization and desalting procedures.

Purification of the small yellow protein by native PAGE. On SDS-PAGE (Fig. 2), the low molecular weight yellow protein, purified by native PAGE, migrated identically as a single band in the absence (lane 6) and presence (lane 5) of 2-mercaptoethanol, suggesting that it had no interchain disulfide bonds. It also corresponded to the yellow protein purified by SDSPAGE (lane 4), and the yellow protein present in the eluate from Sephadex G25 of the demineralized residue from cholesterol gallstones (lane 3). Comparison with protein standards below $13 \mathrm{kD}$ (lane 2) indicated that the molecular weight of the purified protein was $<10 \mathrm{kD}$. This differed from the $12 \mathrm{kD}$ suggested in our preliminary report (32), a value that had been crudely estimated by comparison only with standards of 14 to $97 \mathrm{kD}$ (lanes 1 and 7). Due to spreading of the protein bands, SDS-PAGE in $15 \%$ acrylamide gel did not yield a more accurate molecular weight.

Amino acid composition of the small protein, purified by $S D S-P A G E$. Amino acid compositions of the purified small protein from two different stones agreed closely and grossly resembled the amino acid composition of the whole stone proteins (Table I). The small protein contained $24 \%$ acidic residues, more than three times the proportion of basic residues $(7 \%)$. Aliphatic residues accounted for $\sim 46 \%$ and hydroxylated residues $10 \%$. No tyrosine was present and there were minimal sulfur-containing amino acids (methionine and half cysteine), consistent with the apparent absence of disulfide bonds (see above). The presence of 2-5 residue \% of taurine

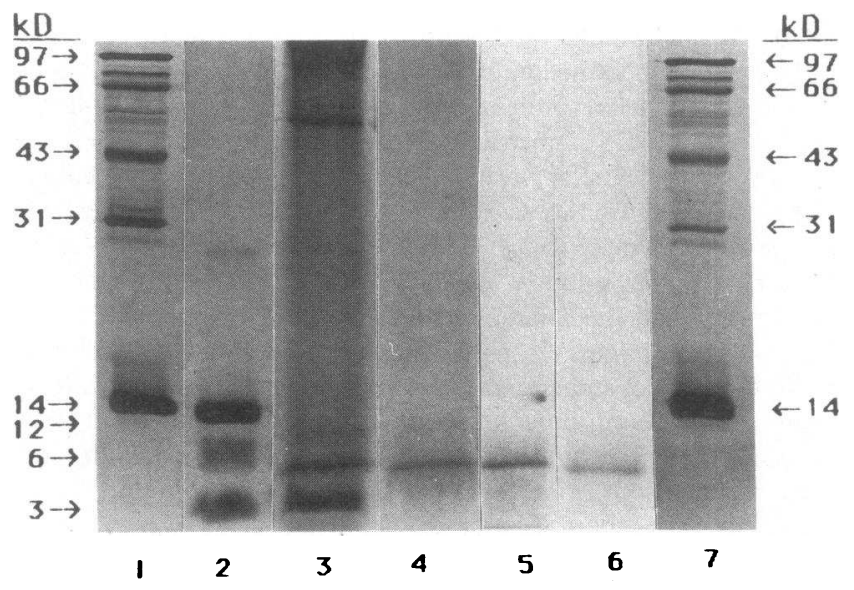

Figure 2. SDS-PAGE (12\% polyacrylamide) of the purified protein from cholesterol gallstones. Lanes 1 and 7 , low molecular weight standards; lane 2, a mixture of cytochrome $c(12.3 \mathrm{kD})$, trypsin inhibitor $(6.2 \mathrm{kD})$ and insulin $(3 \mathrm{kD})$; lane 3 , the eluate from Sephadex-G25 of demineralized residue from cholesterol gallstones; lane 4, the small acidic protein, purified by SDS-PAGE; lane 5 , the protein purified by native PAGE; lane 6 , the purified protein without mercaptoethanol. 
(not listed in Table I), which is found in conjugated bile salts but not proteins, suggests that the high glycine content reflected in part contamination by glycine-conjugated bile acids. The protein contained $1.5 \% \mathrm{~N}$-acetyl glucosamine but undetectable $N$-acetyl galactosamine. Analysis of a control area of the gel, free of protein, revealed that all glycine from the preparative electrophoresis and elution buffers had been removed by the subsequent gel filtration and dialysis of the eluted protein.

Precipitation of the stone proteins by $0.5 \mathrm{M}$ calcium chloride. Among the proteins from two gallstones, eluted from Sephadex-G25 after demineralization, the small yellow protein was the principal protein precipitated by $0.5 \mathrm{M}$ calcium chloride (Fig. 3, lanes 4 and 7). Precipitation was nearly complete, as only traces of this small protein remained in the supernatant (lanes 3 and 6 ). In contrast, there was only limited precipitation by calcium of proteins of $\sim 10,60$, and $70 \mathrm{kD}$.

Nature and binding of the yellow pigment in the protein. The purified small gallstone protein was strongly diazo-positive, suggesting that the yellow pigment was bilirubin or a derivative. Table II summarizes the dialyzability of pigment from proteins in the presence of urea and 2-mercaptoethanol. In the dialysands, the OD of the yellow gallstone protein remained almost unchanged, whereas that of the noncovalent HSA-UCB complex decreased by about half. Correspondingly, the OD of the dialysate from the HSA-UCB control increased 10-fold compared with the dialysate from the yellow gallstone protein. During the 40-h dialysis, degradation of the pigment, calculated from the change in OD $\times$ vol, was $\sim 10 \%$.

Inhibition by the purified protein of calcium carbonate precipitation. The purified small yellow protein markedly inhibited calcium carbonate precipitation in vitro, as shown in Fig. 4. At a final concentration of $10 \mu \mathrm{g} / \mathrm{ml}$, the protein almost completely arrested formation of calcium carbonate macrocrystals, as assessed by the minimal change in OD at $570 \mathrm{~nm}$ over the 15-min period and the arrest in the decline in $\mathrm{pH}$ after

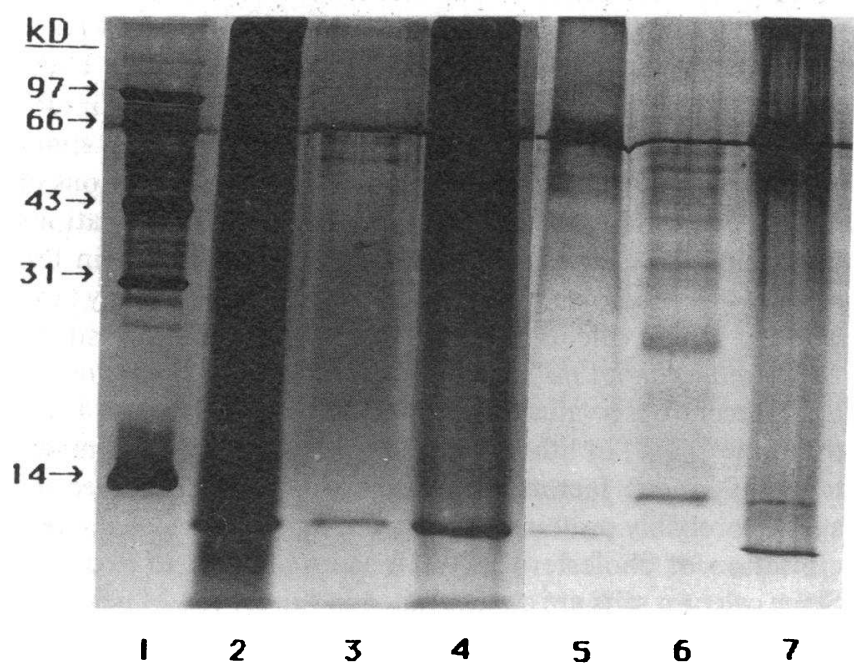

Figure 3. SDS-PAGE of the proteins precipitated from two cholesterol gallstone extracts by $0.5 \mathrm{M} \mathrm{CaCl}_{2}$. Lanes $2-4$ are from one stone and lanes 5-7 are from another. Lane 1, low molecular weight standards; lanes 2 and 5 , the eluate of demineralized residue from Sephadex G25; lanes 3 and 6, the supernatant after the addition of $\mathrm{CaCl}_{2}$; lanes 4 and 7 , the proteins precipitated by calcium.
Table II. Dialyzability of the Pigment from the Pure Small Yellow Gallstone Protein in the Presence of Urea and 2-Mercaptoethanol*

\begin{tabular}{lccc}
\hline & & \multicolumn{2}{c}{ Final OD } \\
\cline { 3 - 4 } & $\begin{array}{c}\text { Initial OD } \\
\text { Dialysand }\end{array}$ & Dialysand & Dialysate \\
\hline Gallstone yellow protein & 1.08 & 0.906 & 0.009 \\
Albumin-bilirubin complex & 1.07 & 0.509 & 0.089 \\
\hline
\end{tabular}

* For the gallstone yellow protein, OD was monitored at $440 \mathrm{~nm}$, and for albumin-bilirubin complex at $420 \mathrm{~nm}$. Dialysis was carried out at $4^{\circ} \mathrm{C}$ for $40 \mathrm{~h}$ in the dark without any change of buffer.

the first $30 \mathrm{~s}$. The initial steep decline in $\mathrm{pH}$ was not inhibited, since it is due to formation of soluble complexes of calcium bicarbonate and carbonate after mixing of the $\mathrm{NaHCO}_{3}$ and $\mathrm{CaCl}_{2}$ solutions. By contrast, no significant inhibition of precipitation occurred with addition of the eluate from the protein-free portion of the PAGE gel, or with the same concentrations of HSA, without and with bilirubin bound noncovalently at a UCB/HSA molar ratio of 2:1.

\section{Discussion}

There are several notable findings in this report: (a) Acidic proteins were present in cholesterol gallstones; as a whole, these proteins are similar in amino acid composition to those found in the extracellular matrix of other mineralized tissues (20). (b) Each of the 13 cholesterol gallstones analyzed contained one major, very low molecular weight, highly acidic protein, that bound bilirubin tightly and inhibited precipitation of calcium carbonate in vitro.

Composition of whole gallstone proteins. As a group, the proteins from the cholesterol gallstones were mainly small and were highly acidic due to a high content of aspartate and glutamate residues. The presence of 2.5 residue $\% N$-acetyl glucosamine suggests that at least some of them are also glycoproteins. They are thus similar to small, acidic, calcium-binding glycoproteins that are found in, and regulate the formation of many biomineralized products in nature (33), for example molluscan shells (21), and bones and teeth in higher animals

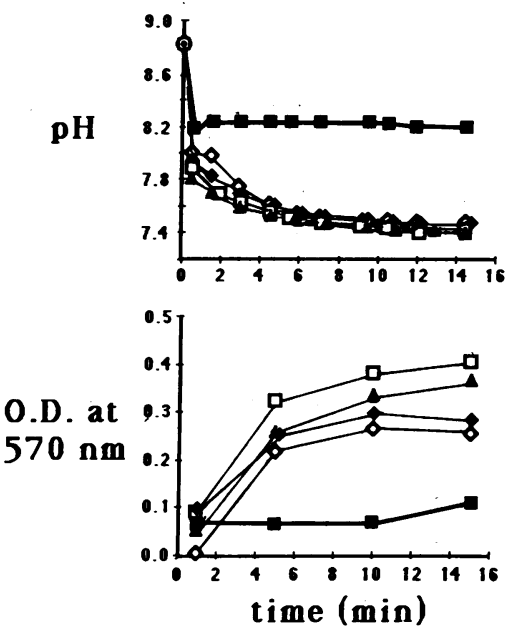
$\mathrm{CaCO}_{3}$ precipitation in vitro by the PAGE-purified protein from cholesterol gallstones. \pm , the purified protein; $\square$, (HSA); $\triangle$, bilirubin bound to HSA (2:1); •, $0.15 \mathrm{M} \mathrm{NaCl} ; \diamond$, control area from SDS-PAGE. The final concentration of each protein sample in the system was adjusted to $10 \mu \mathrm{g} / \mathrm{ml}$, based on the Bio-Rad protein assay.
Figure 4. Inhibition of 
(22). The molecular weights of these proteins vary among different systems, but are generally below $30 \mathrm{kD}(20,33)$. Such proteins regulate biomineralization in part through their acidic amino acid residues, which bind calcium ions at $6.9 \AA$ intervals, the exact distance between calcium ions along the $c$-axis of the crystal lattices of calcium carbonate and phosphate (33). Aspartate and glutamate, which together comprised $\sim 21 \%$ of the amino acid residues in gallstone proteins, are also the major acidic amino acids in noncollagenous proteins of bone (22), in phosphophoryn, the acidic protein from dentin (22), and in proteins found in pathological cardiovascular calcifications $(34,35)$. Highly acidic proteins, rich in aspartate and glutamate, have been found also in human urinary (23) and pancreatic (24) stones, which have been viewed as abnormal, ectopic biomineralization processes, regulated by these proteins $(23,24)$. The acidic proteins in gallstones might play a similar role in gallstone formation.

Gla is often the principal residue in proteins that bind calcium $(36,37)$, including prothrombin $(38)$ and the proteins in pathological calcifications of connective tissues, muscles, joints, and cardiovascular tissues (37). Gla is present also in nephrocalcin, a normal urinary protein that inhibits precipitation of calcium oxalate in vitro, but is missing from the related protein isolated from urinary calcium oxalate stones and the urine of the patients with these stones (23). It has been proposed that this is a molecular defect (possibly genetic) that accounts for the precipitation of calcium oxalate stones in the urinary tract of these patients (23). We specifically searched for, but did not detect Gla in cholesterol gallstone proteins. Compared with kidney stones, Gla may well be found in related proteins in normal bile from patients without gallstones.

The small acidic protein in cholesterol gallstones. One gallstone protein was of particular interest, since it was the only small protein that was detected in each of the 13 cholesterol stones, and it bound pigment tightly (see below). Like proteins in biomineralization systems, this protein contained three times as many acidic as basic amino acids. Since highly charged proteins may migrate anomalously on SDS-PAGE, especially when they have small mol wt (39), the molecular weight of this protein can only be estimated as $<10 \mathrm{kD}$. Moreover, the substituent glycans and bilirubin contribute to the molecular weight of this protein, and may alter its physical and electrophoretic properties. This may explain why a sharp band was not obtained for this protein on $15 \%$ polyacrylamide gels.

The content of $1.5 \% \mathrm{~N}$-acetyl glucosamine suggests that the small protein is a glycoprotein. This is not unexpected. Many noncollagenous proteins in bone and dentin are glycosylated (22), and the acidic proteins in urinary (40) and pancreatic (41) stones contain, respectively, 4 and $2 \mathrm{~mol}$ of neutral sugar $/ \mathrm{mol}$ of protein.

Nature and binding of the yellow pigment(s) in the small acidic protein. Due to the affinity of bile pigments for the resin (42), Sephadex G25 gel filtration removed $50-80 \%$ of the yellow pigments in the demineralized stone residue. In contrast, the remaining yellow pigments stayed firmly bound to the small protein, even when exposed to the detergent in SDSPAGE, or to denaturing agents during dialysis. These data indicate that the binding of bilirubin to this protein is much stronger than that of bilirubin to albumin, whose dissociation constants are in the range of $10^{-7}$ to $10^{-8} \mathrm{M}(43)$. It may well be that the pigment is covalently bound to the protein, akin to the delta-bilirubin covalently bound to plasma albumin in pa- tients and rats with prolonged conjugated hyperbilirubinemia $(44,45)$.

Relationship to other proteins in gallstones and bile. Compatible with our rationale that biliary proteins relevant to gallstone formation might be selectively concentrated in gallstones, only a limited number of the major proteins identified previously in bile (46) were found among the stone proteins, including albumin, and the $130-\mathrm{kD}$ cholesterol-nucleating glycoprotein reported by Groen et al. (7). Although we observed proteins of $>200 \mathrm{kD}$ on SDS-PAGE, which were presumably mucins $(47,48)$, the whole stone protein did not exhibit the high percentages of serine, threonine, proline, or $\mathrm{N}$-acetyl galactosamine that are typical of mucins (49).

Murray and Smith (50) reported the existence of five nonmucin proteins in cholesterol gallstones, but did not further characterize them. Recently, Martigne et al. described a 10-kD acidic protein in cholesterol gallstones (51), which, like our small protein, bound bile pigments preferentially and was rich in aliphatic amino acids; however, their protein contained some cysteine and methionine. The $10-\mathrm{kD}$ protein band we observed on SDS-PAGE of some, but not all of the 13 gallstones (Fig. 1, lane 3) might be the same protein as that detected by Martigne et al., although ours was not pigmented. Etter-Kjelsaas and Kuenzle (52) have described a highly acidic $7-\mathrm{kD}$ bilirubin-binding protein in normal human bile, but it differs from the gallstone proteins isolated by us and by Martigne et al. (51) because of its high content of methionine. The gallstone protein of Martigne et al. is also found as an apolipoprotein in bile (53); and we have found a small yellow protein in bile that migrates like our stone protein on SDS-PAGE (32).

Inhibition by the small protein of calcium carbonate precipitation in vitro. The small yellow protein inhibited precipitation of calcium carbonate in vitro, in a system that is vastly more supersaturated with calcium carbonate than is bile. Moreover, this occurred with concentrations of this protein as low as $2 \mu \mathrm{g}$ per $\mathrm{ml}$, which is at least two orders of magnitude less than the whole protein concentration in human gallbladder bile (54). The protein is clearly a powerful inhibitor of calcium salt precipitation, but this effect is not due solely to binding by the protein of sufficient ionized calcium to decrease the ion product of the salt below the solubility product. Thus, in the in vitro test system, the small acidic protein fully inhibited calcium carbonate precipitation at concentrations more than three orders of magnitude less than the concentrations of calcium $(8 \mathrm{mM})$ present, and calcium ion concentrations stayed far above supersaturation throughout the 15 -min test period (19). Moreover, HSA, which binds calcium avidly (15), failed to inhibit calcium carbonate precipitation in our study.

Possible role of the protein in cholesterol gallstone formation. Recent observations of a shortened cholesterol "nucleation time" (2-8) in lithogenic biles have suggested the importance of kinetic factors, i.e., nucleating and antinucleating agents, probably proteins, that may promote or retard the precipitation of cholesterol crystals from supersaturated bile. Since calcium salts are concentrated in the centers of nearly all cholesterol gallstones (11-14), and are a major component of biliary "sludge," a known precursor of cholesterol gallstones (55), it has been proposed that precipitation of calcium salts may initiate cholesterol stone formation $(15,16)$. Moore (15) has suggested that, analogous to pancreatic stone formation, binding of calcium to a protein nidus may be the first step in formation of all gallstones. It is thus noteworthy that the small 
acidic protein we purified from cholesterol stones interacted strongly with calcium ions; it was precipitated from solution by high concentrations of calcium and interfered with the precipitation of calcium carbonate in vitro. Admittedly, the phenomena in vitro may differ from those in bile, in part related to differences in the concentrations of the proteins, calcium and anions in the two systems, and in part to the presence in bile of other components not included in the model systems. Moreover, it is known that the same protein can act as a nucleating or antinucleating factor at different concentrations or under different conditions (33). Like our protein, the acidic proteins isolated from urinary (40) and pancreatic (56) stones, as well as from oyster shells (57), all inhibit the in vitro precipitation of calcium oxalate or carbonate, but it remains to be determined whether our protein functions in vivo as a promoter or inhibitor of nucleation.

Since the small acidic protein also bound bilirubin firmly, it could account for the presence of pigment and calcium in the center of "pure" cholesterol gallstones and in the dark rings of mixed cholesterol stones. Possibly, as with urinary and pancreatic stone proteins, alterations in the molecular structure (23) or concentration (58) of the related protein we have just identified in bile (32) lead to the precipitation of calcium salts, which carry the abnormal protein and attached bilirubin with them into the nidus of the developing gallstone.

\section{Acknowledgments}

We gratefully acknowledge the generous gifts of cholesterol gallstones by Dr. Steven M. Strasberg, Department of Surgery, University of Toronto, Ontario, Canada and the expert assistance of Ms. Ruth Fullerton in the amino acid analyses.

This work was supported by a research grant from the National Institutes of Health, 2-RO1-DK-32130, and by the Otho S. A. Sprague Fund at Northwestern University.

\section{References}

1. Admirand, W. H., and D. M. Small. 1968. The physicochemical basis of cholesterol gallstone formation in man. J. Clin. Invest. 47:1043-1052.

2. Holan, K. R., R. T. Holzbach, R. E. Hermann, A. M. Cooperman, and W. J. Claffey. 1979. Nucleation time: A key factor in the pathogenesis of cholesterol gallstone disease. Gastroenterology. 77:611-617.

3. Holzbach, R. T., A. Kibe, E. Thiel, J. H. Howell, M. Marsh, and R. E. Hermann. 1984. Biliary proteins. Unique inhibitors of cholesterol crystal nucleation in human gallbladder bile. J. Clin. Invest. 73:35-45.

4. Burnstein, M. J., R. G. Ilson, C. N. Petrunka, R. D. Taylor, and S. M. Strasberg. 1983. Evidence for a potent nucleating factor in the gallbladder bile of patients with cholesterol gallstones. Gastroenterology. 85:801-807.

5. Gallinger, S., R. D. Taylor, P. R. C. Harvey, C. N. Petrunka, and S. M. Strasberg. 1985. Effect of mucous glycoprotein on nucleation time of human bile. Gastroenterology. 89:648-658.

6. Kibe, A., R. T. Holzbach, N. F. LaRusso, and S. T. Mao. 1984. Inhibition of cholesterol crystal formation by apolipoproteins A-I and A-II in model systems of supersaturated bile; implications for gallstone pathogenesis in man. Science (Wash. DC). 225:514-516.

7. Groen, A. K., J. P. J. Stout, C. Noordam, A. Korsen, F. J. Hoek, P. L. M. Jansen, and G. N. J. Tytgat. 1987. Isolation and partial characterization of a cholesterol nucleation promoting factor from human bile. Hepatology. 7:1023. (Abstr.)
8. Groen, A. K., J. P. J. Stout, J. A. G. Drapers, F. J. Hoek, R. Grijm, and G. N. J. Tytgat. 1988. Cholesterol nucleation-influencing activity in T-tube bile. Hepatology. 8:347-352.

9. Somjen, G. J., and T. Gilat. 1983. A non-micellar mode of cholesterol transport in bile. FEBS (Fed. Eur. Biochem. Soc.) Lett. 156:265-268.

10. Halpern, Z., M. A. Dudley, A. Kibe, M. P. Lynn, A. C. Breuer, and R. T. Holzbach. 1986. Rapid vesicle formation and aggregation in abnormal human biles; a time-lapse video-enhanced contrast microscopy study. Gastroenterology. 90:875-885.

11. Palmer, R. H. 1987. The odyssey of a calcium ion. Life in the biliary tract. J. Lab. Clin. Med. 110:375-376.

12. Been, J. M., P. M. Bills, and D. Lewis. 1979. Microstructure of gallstones. Gastroenterology. 76:548-555.

13. Kienzle, H. F., and J. Radtke. 1980. Lokalisation und Verteilung von Calciumsalzen in Gallensteinen. Eine rasterelektronenmikroscopische Untersuchung mit Hilfe der energiedispersiven Elementanalyse. Langenbecks Arch. Chir. 353:171-182.

14. Ananthakrishnan, N., B. N. Balkrishna Rao, and B. M. L. Kapur. 1975. Studies on gall-stone composition-IV. Analysis of gallstones by microchemical methods. Indian J. Med. Res. 63:810-817.

15. Moore, E. W. 1984. The role of calcium in the pathogenesis of gallstones: $\mathrm{Ca}^{++}$electrode studies of model bile salt solutions and other biologic systems. Hepatology. 4:228S-243S.

16. Rege, R. V., and E. W. Moore. 1986. Pathogenesis of calciumcontaining gallstones. Canine ductular bile, but not gallbladder bile, is supersaturated with calcium carbonate. J. Clin. Invest. 77:21-26.

17. Rege, R. V., L. G. Dawes, and E. W. Moore. 1987. $\mathrm{CaCl}_{2}$ addition to canine common duct and gallbladder bile reveals marked metastability with $\mathrm{CaCO}_{3}$. Hepatology. 7:1110. (Abstr.)

18. Sutor, D. J., and J. M. Percival. 1978. The effect of bile on the crystallisation of calcium carbonate, a constituent of gallstones. Clin. Chim. Acta. 89:479-484.

19. Dawes, L. G., J. D. Ostrow, S. Shimizu, E. W. Moore, and R. V. Rege. 1988. Inhibition of $\mathrm{CaCO}_{3}$ precipitation by canine gallbladder bile. Gastroenterology. 94:A534. (Abstr.)

20. Westbroek, P., and E. W. DeJong. 1982. Biomineralization and Biological Metal Accumulation: Biological and Geological. D. Riedel Co., Dodrecht, The Netherlands. 533.

21. Weiner, S. 1979. Aspartic acid-rich proteins. Major components of the soluble organic matrix of mollusk shells. Calcif. Tissue Int. 29:163-167.

22. Veis, A. 1984. Bones and teeth. In Extracellular Matrix Biochemistry. K. A. Piez and A. H. Reddi, editors. Elsevier/North Holland, New York. 329-374.

23. Nakagawa, Y., M. Ahmed, S. L. Hall, S. Deganello, and F. L. Coe. 1987. Isolation from human calcium oxalate renal stones of nephrocalcin, a glycoprotein inhibitor of calcium oxalate crystal growth: Evidence that nephrocalcin from patients with calcium oxalate nephrolithiasis is deficient in gamma-carboxyglutamic acid. J. Clin. Invest. 79:1782-1787.

24. De Caro, A., L. Multigner, H. Lafont, D. Lambardo, and H. Sarles. 1984. The molecular characteristics of a human pancreatic acidic phosphoprotein that inhibits calcium carbonate crystal growth. Biochem. J. 222:669-677.

25. Ohkubo, H., J. D. Ostrow, S. H. Carr, and R. V. Rege. 1984. Polymer networks in pigment and cholesterol gallstones assessed by equilibrium swelling and infrared spectroscopy. Gastroenterology. 87:805-814.

26. Laemmli, U. K. 1970. Cleavage of structural proteins during the assembly of the head of bacteriophage $\mathrm{T}_{4}$. Nature (Lond.). 227:680-685.

27. Wray, W., T. Boulikas, V. P. Wray, and R. Hancock. 1981. Silver staining of proteins in polyacrylamide gels. Anal. Biochem. 118:197-203.

28. Lee, S. L., A. Veis, and T. Glonek. 1977. Dentin phosphoprotein: an extracellular calcium-binding protein. Biochemistry. 16:2971-2979. 
29. Michaelsson, M., B. Nosslin, and S. Sjolin. 1965. Plasma bilirubin determination in the newborn infant: a methodological study with special reference to the influence of hemolysis. Pediatrics. 35:925-931.

30. Kuenzle, C. C., N. Gitzelmann-Cumarasamy, and K. J. Wilson. 1976. Affinity labeling of the primary bilirubin binding site of human serum albumin. J. Biol. Chem. 251:801-807.

31. Lauff, J. J., M. E. Kasper, T. W. Wu, and R. T. Ambrose. 1982. Isolation and preliminary characterization of a fraction of bilirubin in serum that is firmly bound to protein. Clin. Chem. 28:629-637.

32. Shimizu, S., B. Sabsay, A. Veis, J. D. Ostrow, L. G. Dawes, and R. V. Rege. 1988. A $12 \mathrm{kDa}$ acidic protein from cholesterol gallstones inhibits precipitation of calcium carbonate and is present in human bile. Hepatology. 8:1257. (Abstr.)

33. Veis, A., and B. Sabsay. 1982. Bone and tooth formation; insights into mineralization strategies. Biomineralization and Biological Metal Accumulation: Biological and Geological. D. Riedel Co., Dodrecht, The Netherlands. 273-284.

34. Levy, R. J., J. B. Lian, and P. Gallop. 1979. Atherocalcin, a $\gamma$-carboxyglutamic acid containing protein from atherosclerotic plaque. Biochem. Biophys. Res. Commun. 91:41-49.

35. Levy, R. J., J. Zenker, and J. B. Lian. 1980. Vitamin K-dependent calcium binding proteins in aortic valve calcification. J. Clin. Invest. 65:563-566.

36. Stenflo, J., and J. W. Suttie. 1977. Vitamin K-dependent formation of gamma-carboxyglutamic acid. Annu. Rev. Biochem. 46:157-172.

37. Lian, J. B., R. J. Levy, J. T. Levy, and P. A. Friedman. 1980. Other vitamin $\mathrm{K}$ dependent proteins. In Calcium-binding Proteins: Structure and Function. F. L. Siegel, E. Carafoli, R. H. Kretsinger, D. H. MacLennan, and R. H. Wasserman, editors. Elsevier/North Holland, New York. 449-460.

38. Stenflo, J., P. Fernlund, W. Egan, and P. Roepstorff. 1974. Vitamin $\mathrm{K}$ dependent modifications of glutamic acid residues in prothrombin. Proc. Natl. Acad. Sci. USA. 71:2730-2733.

39. Swank, R. T., and K. D. Munkres. 1971. Molecular weight analysis of oligopeptides by electrophoresis in polyacrylamide gel with sodium dodecyl sulphate. Anal. Biochem. 39:462-477.

40. Nakagawa, Y., V. Abram, F. J. Krezdy, E. T. Kaiser, and F. L. Coe. 1983. Purification and characterization of the principal inhibitor of calcium oxalate monohydrate crystal growth in human urine. $J$. Biol. Chem. 258:12594-12600.

41. Montalto, G., J. Bonicel, L. Multigner, M. Rovery, H. Sarles, and A. De Caro. 1986. Partial amino acid sequence of human pancreatic stone protein, a novel pancreatic secretory protein. Biochem. J. 238:227-232.

42. Kaufman, N. A., J. Kapitulnik, and S. H. Blondheim. 1969. The adsorption of bilirubin by Sephadex and its relationship to the criteria for exchange transfusion. Pediatrics. 44:543-548.

43. Brodersen, R. 1986. Aqueous solubility, albumin binding and tissue distribution of bilirubin. In Bile Pigments and Jaundice; Molec- ular, Metabolic and Medical Aspects. J. D. Ostrow, editor. Marcel Dekker, Inc., New York. 157-181.

44. Weiss, J. S., A. Gautam, J. J. Lauff, M. W. Sundberg, P. Jatlow, J. L. Boyer, and D. Seligson. 1983. The clinical importance of a protein-bound fraction of serum bilirubin in patients with hyperbilirubinemia. N. Engl. J. Med. 309:147-150.

45. Gautam, A., H. Seligson, E. R. Gordon, D. Seligson, and J. L. Boyer. 1984. Irreversible binding of conjugated bilirubin to albumin in cholestatic rats. J. Clin. Invest. 73:873-877.

46. Reuben, A. 1984. Biliary proteins. Hepatology. 4:4S-14S.

47. Smith, B. F., and J. T. LaMont. 1985. Identification of gallbladder mucin-bilirubin complex in human cholesterol gallstone matrix; effect of reducing agents on in vitro dissolution of matrix and intact gallstones. J. Clin. Invest. 76:439-445.

48. Pearson, J. P., and S. N. E. Foster. 1987. Mucous glycoprotein content of human cholesterol gallstones. Digestion. 36:132-140.

49. Smith, B. F., and J. T. LaMont. 1984. Hydrophobic binding properties of bovine gallbladder mucin. J. Biol. Chem. 259:1217012177.

50. Murray, F. E., and B. F. Smith. 1987. Non-mucin proteins in the organic matrix of cholesterol gallstones. Gastroenterology. 92:1758. (Abstr.)

51. Martigne, M., N. Domingo, P. Lechene de la Porte, H. Lafont, and J. Hauton. 1988. Identification and localization of the apoprotein fraction of the bile lipoprotein complex in human gallstones. Scand. J. Gastroenterol. 23:731-737.

52. Etter-Kjelsaas, H., and C. C. Kuenzle. 1975. A polypeptide conjugate of bilirubin from human bile. Biochim. Biophys. Acta. 400:83-94.

53. Martigne, M., N. Domingo, H. Lafont, G. Nalbone, and J. C. Hauton. 1985. Purification of the human anionic polypeptide fraction of the apo-bile lipoprotein complex by zonal ultracentrifugation. Lipids. 20:884-889.

54. Yamazaki, K., S. P. Powers, and N. F. LaRusso. 1988. Biliary proteins: Assessment of quantitative techniques and comparison in gallstone and non-gallstone subjects. J. Lipid Res. 29:1055-1063.

55. Carey, M. C., and M. J. Cahalane. 1988. Whither biliary sludge. Gastroenterology. 95:508-523.

56. Multigner, L., A. De Caro, D. Lombardo, D. Campese, and H. Sarles. 1983. Pancreatic stone protein, a phosphoprotein which inhibits calcium carbonate precipitation from human pancreatic juice. Biochem. Biophys. Res. Commun. 110:69-74.

57. Wheeler, A. P., J. W. George, and C. A. Evans. 1981. Control of calcium carbonate nucleation and crystal growth by soluble matrix of oyster shell. Science (Wash. DC). 212:1397-1398.

58. Multigner, L., H. Sarles, D. Lombardo, and A. De Caro. 1985. Pancreatic stone protein. II. Implication in stone formation during the course of chronic calcifying pancreatitis. Gastroenterology. 89:387391. 